\title{
酵母菌における増死・分化の調節機構に関する研究†
}

\author{
（1990 年度農芸化学奖励賞受賞）
}

\section{土 屋 英子}

(広島大学工学部)

酔母は主として出芽により增殖する菌類の総称でする が，このらち有性世代の存在が知られているものに子の う酵母と異担子菌酵母がある。これらの1倍体細胞には 2つ，または 4 つの接合型があり各接合型細胞は接合型 特異的な性フェロモンを生産・分泌する、またこれらは 相手接合型性フェロモンを受容して性接合が可能な生殖 細胞へと分化する能力又持つ. 性フェロモンによる細胞 の分化は細胞の增殖周期之深い関連を持ち, 細胞分裂の 完了から DNA 複製開始に至る時期 (G1 期) 内の特定 の時期に起こる。このように酔母は真核生物の增殖・分

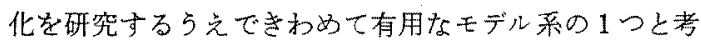
充らる、本研究は真核細胞の增殖・分化の調節機構解 明の系口を得ることを目的とし，異担子菌酵母 Rhodosporidium toruloides, Tremella mesenterica, 子のう酵 母 Saccharomyces cerevisiae の性フェロモン(ロドトル シン $A$, トレ×ロジェン $A-10$, および $\alpha$ 因子) の生理作 用ならびに細胞周期の調節之核機能の発現について解 析を行ったものである.

1. 異担子菌酵母の性フェロモンとフェロモン情報の トランスメンブレンシグナリング

異担子菌酵母 T.mesenterica には 4 つの接合型 $(A B$, $A b, a B, a b)$ が存在し， $A$ を持つ妇のは $A$ 型のフェ口 モンを， $a$ を持つものは $a$ 型の性フェロモンを構成的に 生産, 分泌している. 同様に異担子菌醉母 $R$. toruloides には $2 つ の$ 接合型 $(A, a)$ が存在し, この5 のみが構成的に性フェロモンを生産し， $a$ 型細胞は $A$ 型 フェロモンに応答して生産するようになる，筆者らは理

$t$ A Study on the Controls of Growth and Feromonal Response in Yeasts.

Eiko TSUCHIYA (Department of Fermentation Technology, Faculty of Engineering, Hiroshima University, Higashihiroshima 724)
化学研究所神谷勇治博士, 現名古屋大学坂神洋次博士 5 之の共同研究により T. mesenterica の $\mathrm{AB}$ 型細胞, 执よ び R.toruoides A 型細胞の分泌する性フェロモンを単 離精製しその化学構造を洪定した結果，これらがいずれ もペプチドのC 末端にSーファルネシルシステインを持 つ新規なリポペプチドであることを明らかにした（図 $1)^{(1 \sim 3)}$.このよらな特異な $\mathrm{C}$ 末端構造は最近子のら酔 母. cerevisiae $の a>ェ$ モン $(a \text { 因子 })^{(4)}$, 発癌遺伝 子の1つである RAS 蛋白 ${ }^{(5)}$ 等にも見出され興味が持た れている、李た，フェロモンが生物活性を発現するため にはいずれのフェロモンに括いてもその全構造が必要て あることを明らがしだ活。

$R$.toruloides $の A$ 型フェロモン（ロドトルシンA） を受容菌 $a$ 細胞に加えると急激に上清中の活性吕低下 した (図 2$)^{(7)}$.この現象は $0 \sim 4^{\circ} \mathrm{C}$ の低温下でも起こる ことから最初われわれはフ品れンのレヒプタ一への結 合によると考皇たがその後の解析の結果この現象はフェ 口モン分子の C 末端側か54番目の Arg 上3番目の Asn 間のトリプシン型エンドペプチダ一ゼの切断反応 によるものであることが判明しだ(8). このェンドペブチ ダーゼは $a$ 型細胞の細胞膜に存在し，この酵素の特異 的阻害成(トシルアルギニンィチルエステル、アンチ パイン，チォール基修飾酵素など）が細胞の生育に全く 影響を与えずにフェロモン作用のみを阻害することこ の酵素を欠く変異体が取得されこの株はロドトルシン゙ $A$ に対与る応答性を欠いていたことここ活性は $a$ 型 紐胞に特異的で $A$ 型細胞には存在しないことが明らが になり，本䤃素は性フェロモンのシグナル伝達に必須な

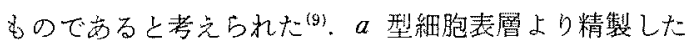
醉素（トリガーペプチダーゼと呼ぶ）は分子量約 $63 \mathrm{~K}$ の糖蛋白で基筫特異性がき放めて高いといら特街を有し ていた，表 1 に示すように本酵素は完全な形のロドトル シン $A$ のみ女分解し，フェロモンのペプチド部分のみ 


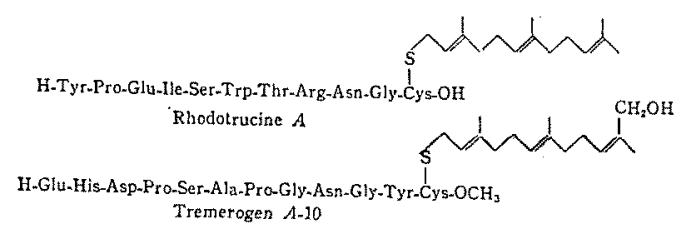

図 1 ロドトルシン $A$,トレメロジン $A-10$ の化学構造

(化学合成)，あるいはプロテアーゼの基礩として一般に 用いられるカゼイン等には全く作用しなかった。また本 醉素は $\mathrm{SH}$ 酵素でさらに反応にホスホりピドと $\mathrm{Ca}^{2+}$ の 存在要求した(10).

$\mathrm{Ca}^{2+}$ は細胞にとって必須な元素であるが通常その細 胞内濃度は $10^{-7} \mathrm{M}$ 程度の低濃度保たれており，多細 胞生物などではての急上帠が笳収縮，ホルモン分泌など の細胞灾答を引き起こすことが知られている，別の実験 によりロドトルシン $A$ の作用時に $\mathrm{Ca}^{2+}$ が必要と考兑 られたことまた前述のようにトリガーペプチダービの 反応が $\mathrm{Ca}^{2+}$ 要求性であったことより口ドトルシン $A$ のシグナル伝達の過程に $\mathrm{Ca}^{2+}$ をセカンドィッセンジャ 一とする経路の存在を予想しフェロモン添加時の ${ }^{45} \mathrm{Ca}^{2+}$ の取り込みを測定した。この結果, フェロモン添加直後 に ${ }^{45} \mathrm{Ca}^{2+}$ の急激で一過的な取り这みの上昇が起こるこ

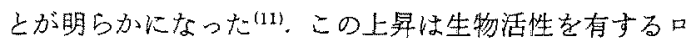
ドトルシン $A$ を添加したときにのみ観察されC端のフ ァルネシル基を欠くフナログなとでは㑇められないこ

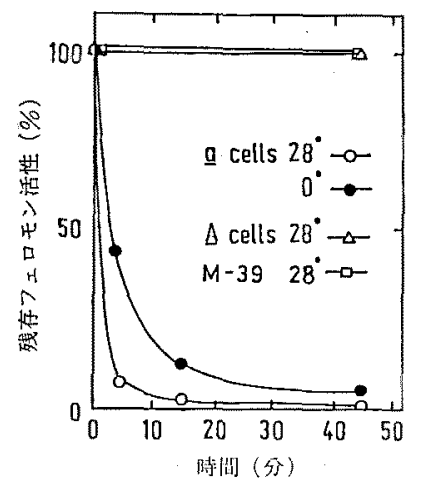

図 $2 a$ 型細胞によるロドトルシンA活性の減少

と， $a$ 型細胞に特巽的であること, 前述のトリガーペプチ タ゚ーゼ活性を欠きフェロモンに応答しない変暴株では認 められないことから性フェ口モンの情報伝達に深くかか， わっていると考光られた，近年動物細胞などにおいては 細胞膜受容体にリガンドが結合することにより，イノシ トールリン脂質の代謝を介した細胞内カルシウムの動員 が起こることが知られてきている.R. toruloides では检 索した限りに和いてこの系の関与を示可結果は得られな かった，一方，細胞に和ける $\mathrm{Ca}^{2+}$ の流入，排出には細

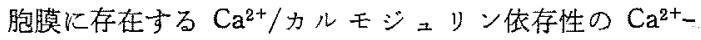
ATPase が関与かることが知られている、與味㳭いこと に $a$ 型細胞膜の $\mathrm{Ca}^{2+}$-ATPase はロドトルシン $A$ によ って dose dependentな阻害を受けることが明らかにな

表 1 トリガーペプチダーゼの基質特異性

\begin{tabular}{lcc}
\hline \multicolumn{1}{c}{ Substrate } & Hydrolysis \\
\hline a) Rhodotorucine $A$ & + \\
b) SH-Rhodotorucine $A$ & - \\
c) Tremerogen a-13 & + \\
d) Tremerogen $A-10$ & - \\
Casein & - \\
BSA & Hemoglobin & - \\
Cytochrome c & - \\
\hline
\end{tabular}

a) H-Tyr-Pro-Glu-Ile-Ser-Trp-Thr-Arg-Asn-Gly-Cys-OH

b) Tyr-Pro-Glu-Ile-Ser-Trp-Thr-Arg-Asn-Gly-Cys

c) $\mathrm{H}-\mathrm{Glu}-\mathrm{Gly}-\mathrm{Gly}-\mathrm{Gly}-\mathrm{Asn}-\mathrm{Arg}-\mathrm{Gly}-\mathrm{Asp}-$ Pro-Ser-Gly-Val-Cys-OH

d) H-Glu-His-Asp-Pro-Ser-Ala-Pro-Gly-Asn-Gyl-Tyr- $\stackrel{1}{\mathrm{C}} \mathrm{ys}-\mathrm{OCH}_{2}$.<smiles>CCSCCCC(C)=CCCC=C(C)CCCC(C)CCO</smiles> 
表 $2 a$ 細胞表層 $\mathrm{Ca}^{2+}-\mathrm{ATPase}$ に対ずる ロドトルシン $A$ の添加効果

\begin{tabular}{|c|c|c|c|c|c|}
\hline \multirow{2}{*}{ 測 } & \multirow{2}{*}{ 定 } & \multirow{2}{*}{ 条 } & \multirow{2}{*}{ 件 } & \multicolumn{2}{|c|}{ ATPase 活性 } \\
\hline & & & & $\mu \mathrm{mol} /$ 分 & $(\%)$ \\
\hline \multicolumn{4}{|c|}{ Complete } & 0.67 & $(100)$ \\
\hline \multicolumn{3}{|c|}{$-\mathrm{Mg}^{2+}$} & & 0.64 & (96) \\
\hline \multicolumn{3}{|c|}{$-\mathrm{CaM}$} & & 0.12 & (18) \\
\hline \multicolumn{3}{|c|}{ 一ホスホリピト } & & 0.38 & (57) \\
\hline \multicolumn{3}{|c|}{ ーロドトルシン $A$} & & 0.00 & $(0)$ \\
\hline \multicolumn{3}{|c|}{ ナロドトルシン $A$} & Sーオキシ & 0.59 & (88) \\
\hline
\end{tabular}

$\mathrm{CaM}$, カルジュリン.

っだ(12) (表 2).さらにこの阻害はロドトルシン $A$ のト リガーペプチダーゼによる水解㢕物（C 末端側のS-フ フルネンルトリペプチドよって多認められた。 た，細胞膜の可溶化物中よりカルモジュリンアフィニテ ィカラムによって部分精製した $\mathrm{Ca}^{2+}$-ATPase 標品中に はトリガーペプチダーゼが存在することここの標品にト リガーベブチダーゼの阻害剤を添加して和くとロドトル シン $A$ による活性阻害が起こらないことなどから，a 型細胞の細胞膜中でトリガーペプチダービと $\mathrm{Ca}^{2+}$ ATPase が複合体を形成して存在し，フェロモン情報の 紐胞内への伝達に働いていると考光ら机だ。

子のう醅母 S. cerevisiae では近年性フェロモン $\alpha$-园 子のシグナリング機構が詳しく調べられこの経路にはレ セブターと結合して存在すると考えられる GTP 結合 蛋白質 (GPAI) の活性調節が関与することが示された (詳細については文献 $13 ， 14$ 参照)。しか乙筆者らはS. cerevisiae の $a$ 細胞が $\alpha$ 因子を受容した際にb $R$. toruloides と同様 $\mathrm{Ca}^{2+}$ の一過的な取り达み上㑭が起こ

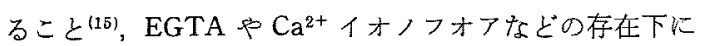
は $\alpha$ 因子の作用が阻害されることを観察して扰り，この 菌のフェロモン作用の過程にも $\mathrm{Ca}^{2+}$ を介した調節系が 存在するものと考光ている.

\section{2. 細胞周期と性フェロン作用}

性フェロモンによって誘導される細胞の変化は異担子 菌酵母では接合管の形成として認められ，子のう醉搏で は細胞凝集お゙よび突起形成と種によって異なるが最も普 遍的に認るられる現象は細胞がもずDNA 複製開始前 （G1 期）の特定の時期に揄って增殖を停止することで ある、このことは性的細胞融合後に引き続いて起こる核 の融台の際に 2 つ核が 1 nの状態を保っていることが
効果的な 2 倍体形成を保障すると考学るときわめて合目 的的な調節であると言之る。性フェロモンによる增殖停 止の時期は Hartwell らの解析により G 1 期の“スター ト”之呼ばれる時期であることが知られている(16)，正常 な増殖に和いてこの時期の通過には $C D C 28, C D C 36$, $C D C 37, C D C 39$ 等の遗伝子の働きが必要である(17). 性 フェロモンの情報がこれらの細胞周期の遗伝子に作用し て増殖停止を引き起こしていると仮定すると，これら遗 伝子火変異を持つ株を親株として己の抑制変買株を取得 すればそのなかに $\alpha$ 因子に耐性なすのが得られるのでは ないか之考竞 $c d c 28$ 株を親株としでスクリーニングを 行ったが，単一変異によって $c d c 28$ を抑制し， $\alpha$ 因子耐 性上なるものは得られなかった。しかしこのとき得られ た $c d c 28$ の抑制変暴株の 1 つは ${ }^{45} \mathrm{Ca}^{2+}$ の取り込又能が 高く、なたカルモジュリンのアンタゴニストとして知ら れるトリフルオペラシンに耐性となっていた(18). 票た別 の実験により制限温度処理によってスタート期に生育を 停止させた $c d c 28$ 株の核内では核の主要な蛋白りン酸 化酵素の 1 つが顕著に低下することを見出した(19).この 酵素は cAMP， $\mathrm{Zn}^{2+}$ などでは活性化されなかったが $\mathrm{Ca}^{2+}$ により活性化を受けた。これらの結果は醅母の細 胞周期においてスタート期の通過の時期にも $\mathrm{Ca}^{2+}$ によ る調節が関与している可能性を示崚している. $\mathrm{Ca}^{2+}$ は ミクロチュープルの脱重合に関与することからM期に和 ける $\mathrm{Ca}^{2+}$ の役割については上く研究が行われている. 酔母に和いても大矢らにより $\mathrm{Ca}^{2+}$ 依存性の変異株を用 いてM期に招ける $\mathrm{Ca}^{2+}$ の役割について解析が進められ ている(20). しかし動物細胞などにおいては発癌プロモー ターの作用により緗胞内の $\mathrm{Ca}^{2+}$ 動貝が起こり静上期の 細胞が增殖期に入り DNA 複製が誘導されることや $\mathrm{S}$ 期直前に $\mathrm{Ca}^{2+}$ ，カルモジェリンの顕著な增加があるこ となどが報告されており，G1 期から S 期への移行にも $\mathrm{Ca}^{2+}$ による調節が働くと考古られる。市た，CDC 28 遗 伝子の産物性真核生物一般に共通して存在する蛋白りン 酸化醉荸でスタート期とM期の雨方で細胞周期の調節に 働くことが知られている。この蛋白は細胞周期を通して 細胞内に一定量存在するがスタート期とM期に特異的な 活性化が起こることが最近明らかにされてきた(21). 現在 この蛋白の活性化機構の詳細は明らかではないが，この 過程に $\mathrm{Ca}^{2+}$ を必要とする反应加存在士ることす考光ら れる、スタート期の調節と $\mathrm{Ca}^{2+}$ のかかわりは前述のよ らに性フェロモンの作用によって細胞内 $\mathrm{Ca}^{2+}$ の変動が 
表 $3 c d c$ 変異栋に扔ける細胞および核内の DNA ポリメラーゼ活性 ${ }^{(25)}$

\begin{tabular}{|c|c|c|c|c|}
\hline \multirow{3}{*}{ 菌 侏 } & \multicolumn{4}{|c|}{ DNAポリメラーセ活性（単位/mg タンパク質） } \\
\hline & \multicolumn{2}{|c|}{ 非同調化細胞 ${ }^{\mathrm{a}}$} & \multicolumn{2}{|c|}{ 同調化 細 胞 ${ }^{b}$} \\
\hline & 細胞 & 核 & 緗胞 & 核 \\
\hline A 364 A & 1.5 & 11.5 & 1.2 & 10.5 \\
\hline$c d c 25$ & 1.5 & 8.9 & 0.9 & 2.4 \\
\hline$c d c 28$ & 1.4 & 13.0 & 1.1 & 2.0 \\
\hline$c d c 4$ & 1.4 & 16.9 & 1.0 & 3.1 \\
\hline$c d c 7$ & 1.3 & 14.1 & 1.4 & 16.4 \\
\hline$c d c 8$ & 1.2 & 11.3 & 0.9 & 7.3 \\
\hline$c d c 3$ & 1.4 & 12.1 & 1.2 & 12.0 \\
\hline
\end{tabular}

活性はすべて許容温度で測定した。

\&許容温度で培盖した細胞.

b 4 時間の制限温度処理を行い $c d c$ 変異で停止させ た緗胞。

起こることを考えあわせるときわめて興味樑い。

\section{3. 酵母の細胞周期における核機能の発現}

さきに述べたよらに性フェロモンの情報が細胞内に伝 達されると細胞は G 1 期のスタート期に生充を停止す る.この機構を生化学的火解析するため S. cerevisiae よ り核の単離法を検討した，酵母は厚い細胞壁に被われて おりり細胞内オルガネラの単離は容易ではない，筆者らは 細胞焦の溶菌酵素処理と機械的破砕法を組み合わせ，比 較的短時間の5ちに損賃の少ない核を単離する方法を確 立した ${ }^{(22)}$. さらにこの単離核よりクロマチンを分画しそ の抽出蛋白を用いて醥母の複製起点を有するプラスミド DNA を鋳型とした in vitro DNA 複製䒺確立し だ(23)。性フェロモンを作用させた細胞や， $c d c$ 変異で $\mathrm{G}$ 1 期に生育を停止させた細胞の核抽出液ではこの in vit
表 $4 \alpha$ 因子で同調化した A 364 A 株の全細胞永よび 核内に和ける DNA ポリメラーゼ活性 ${ }^{(25)}$

\begin{tabular}{|c|c|c|c|}
\hline \multirow{2}{*}{$\alpha \underset{\text { 妈理 }}{\text { 因子 }}$} & \multicolumn{3}{|c|}{ DNAボ!メラーゼ活性（単位/mg タンパク質） } \\
\hline & 細胞 & 校 & 活性比(核/細胞䆬) \\
\hline- & 1.5 & 11.5 & 2.3 \\
\hline+ & 1.1 & 4.2 & 0.53 \\
\hline
\end{tabular}

¿細胞貿中の醉素活性は，核と細胞のタンパク含量の 比が 1：11であるとい5実娩結果に基ついて次式か ら算出した。

細胞質中の活性 $=$ 全細胞の活性 $\times 11$ 一核の活性。

ro DNA 複製活性は著しく低かった，また効数增殖期の 細胞質中にはこの in vitro DNA 複整を促進する活性が 認められたが，静止期の細胞や性フェロモンを作用させ た細胞中にはこのような活性は汪とんど認められなかっっ た(24). DNA 複製はきわめて多種類の蛋白が共赲するこ とによって開始，進行するがこのなかでも DNA ポリメ ラーゼはその中心的な作用を担っている. したか゚って in vitro DNA 複製系の活性化は細胞質中のDNA ポリ ஃラーゼによるこ上も考光られる。そこで $\mathrm{G} 1$ 期から $\mathrm{S}$ 期の各時期に $c d c$ 变異, および $\alpha$ 因子を用いて同謂化し た細胞を用い，全細胞，および核内の DNA ポリィラー ゼ活性を測定しだ、この結果，表 3 に示すよ5に全細胞 のポリメラーゼ活性はどの時期の細胞でも结ぼ一定です るのに対し，核内の活性は G 1 期の前期ではきわめて低 $く ， G 1$ 期徯期の DNA 複製開始直前に上杽すること学 明らかにしだ(25) (表 3). 核内の DNA ポリメラーゼレ ベルの低下は $\alpha$ 因子で処理して G 1 期停止した細胞で も認められたが細胞全体の活性は他の細胞と変化がなか った(表 4).

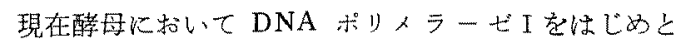

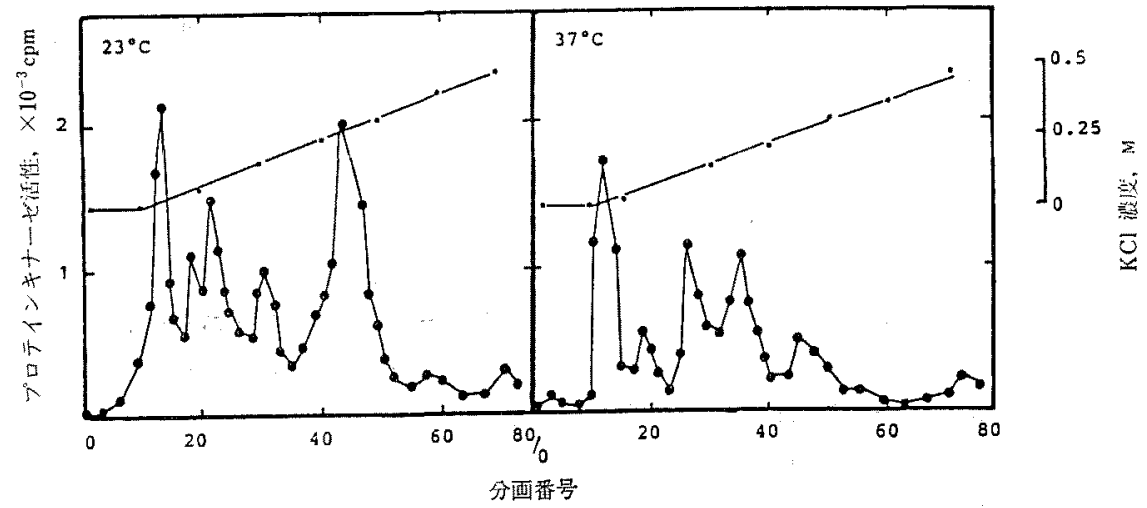

図 3 S. cerevisiae cdc 28 株核抽出液中のプロティンキナーゼの DEAE七ルロースカラムクロマトグラム 


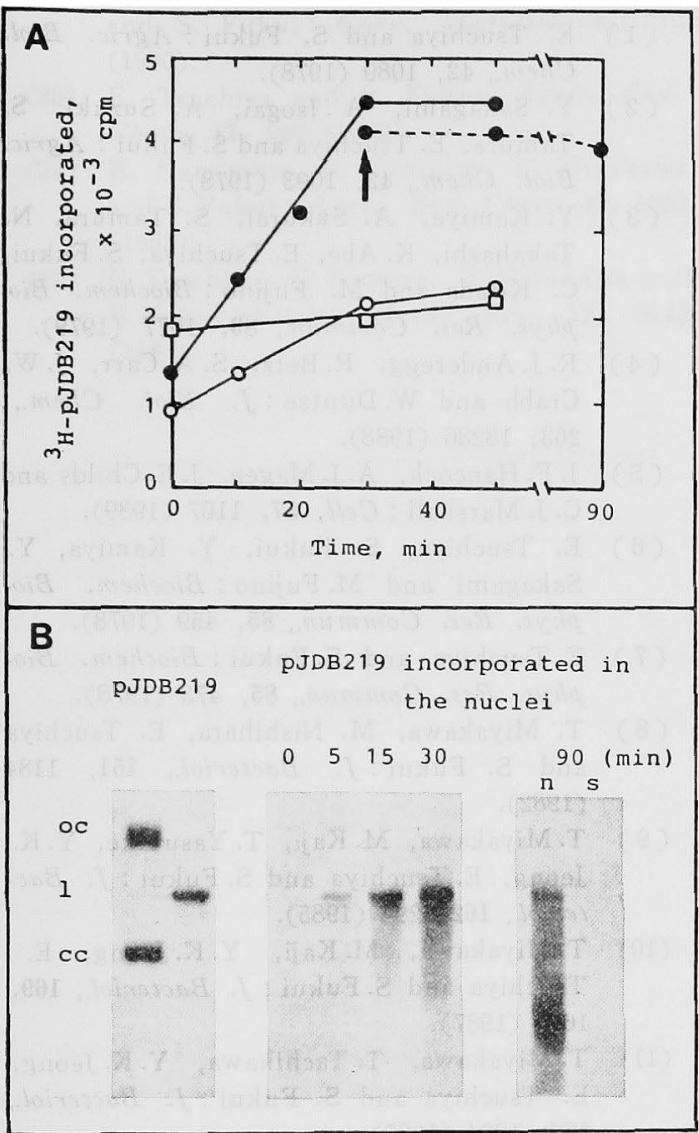

図 4 S.cerevisiae 単離核による pJDB219 の取り込み $\mathrm{A}$ : 取り込及反応の時閒経過 : - - $-28^{\circ} \mathrm{C}$; $-0-, 2^{\circ} \mathrm{C} ;-\square-, N P-40$ 処理核, $28^{\circ} \mathrm{C}$

B : in vitro 反応で核内に取り込まれた $\mathrm{pJDB}$ 219 のサザンブロット解析
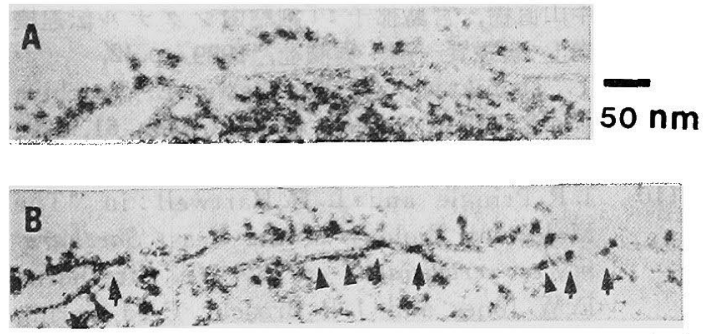

図 5 単離核に拈けるWGA 結合物質の電子顕徽鏡観察

A，朱染色; B, ビオチン化 WGA とストレプト アビジンービオチン化ペルオキシダーゼによる酵 素染色を行ったもの，矢印の部分に酵素反応で生 した高電子密度産物の沈着が認められる.

していくつかの DNA 複製にかかわる醉素の遺伝子が 取得され細胞周期におけるその発現が解析されている. しかしこれら遗伝子の発現量の細胞周期に伴ら変動はい
ずれも S 期にのみその産物が働くことを説明するほどに 大きなものではない、汭).このよらな DNA 複製にかか わる酵素も他の蛋白之同様細胞質で合成された後核内に 輸送される、したがってS期にのみ働くこれらの䤃素は 核内への輸送または核内での保持の段階で調節を受けて いる可能性がある. 筆者らの得た結果络細胞周期におい て蛋白の核への局在化を支觉る何らかの機構が存在する ことを示唆している.

\section{4. 酵母の単離核による核膜を介した物質輸送系の解} 析

性フェロモンの情報は細胞膜上のレセプターで認識さ れた後, 多くの生化学反応を介して核内に伝達され細胞 増殖の停止, ならびに生殖細胞特異的遺伝子の発現が誘 起される. 前述のようにレセプターから細胞内への情報 伝達には $\mathrm{Ca}^{2+} や \mathrm{GTP}$ 結合蛋白が重要な働きをするこ とが明らかになったが現在いずれの酵母においても核内 への情報の伝達機構は全く明らかではない，核は 2 重の 膜系によって包まれた構造を持ち、細胞質から核内への 物質の輸送はこの 2 重膜を貫通して存在する核孔を通じ て行われる。この翰送はきわめて敩格な制御を受けてお り分子量 $30 \mathrm{~K}$ 以上の分子は通過しにくく, $60 \mathrm{~K}$ 以上の ものは通過できない(27). しかし核内には高分子の蛋白が 取り込まれ，また mRNAやリボソームサブニニットが 核外一輸送される.性フェロモンによって核内へ伝えら れる情報物質もおそらく特殊な蛋白分子ではないかと予 測され，この核内への情報伝達の機構を解析するために はまず有効な in vitro 系の確立が必要であると考皇ら れた. そこでこの系の確立のため基質として検出・同定 が容易で高分子であるプラスミド DNA（pJDB 219,

分子量約 $7.4 \mathrm{M}$ ) を用い単離核による in vitro 輸送系の 確立を試みこれに成功した(28). S. cerevisiae の単離核を ${ }^{3} \mathrm{H}$ ラベルした pJDB 219 と incubate すると温度, 時間 に依存したプラスミドの核内への蓄積が観察された（図 4 ). この反応は $\mathrm{ATP}, \mathrm{Mg}^{2+}$ を要求しまた各種酵素阻 害剤を用いた実験によりこの反応には核のATPase, 覔 白リン酸化酵素が働いていることを明らかにした。さら にこの in vitro 輸送反応が小麦肧芽レクチンによって 強く阻害されることを見出した ${ }^{(29)}$. WGA の局在部位を 電子顕微鏡観察によって調べた結果 WGA は核孔付近 に結合していることを明らかにした（図 5 ). そこで㤥 膜の抽出物をWGA アフィニティカラムで分画した結 
表 5 酵母核膜の WGA 結合性 ATPase に対する 各種阻害創の影響

\begin{tabular}{|c|c|c|c|}
\hline 阻 & 害 & 齋 & $\begin{array}{l}\text { ATPase 活性 } \\
\text { (Pi の遊離, } \mathrm{cpm} / 5 \text { 分) }\end{array}$ \\
\hline \multicolumn{3}{|c|}{ な } & $2188(100)$ \\
\hline \multicolumn{3}{|c|}{$+\mathrm{NaN}_{3}(10 \mathrm{mM})$} & $2046(94 \pm 2)$ \\
\hline \multicolumn{3}{|c|}{ +ケルセチン $20 \mu \mathrm{g} / \mathrm{ml})$} & $2117(96 \pm 5)$ \\
\hline \multicolumn{3}{|c|}{ +バナジン酸 $\mathrm{Na}(2 \mathrm{mM})$} & $2074(92 \pm 5)$ \\
\hline \multicolumn{3}{|c|}{$+\operatorname{DCCD}(1.5 \mathrm{mM})$} & $2281(102 \pm 2)$ \\
\hline \multicolumn{3}{|c|}{$+\operatorname{EDTA}(1 \mathrm{mM})$} & $403(20 \pm 2)$ \\
\hline \multicolumn{3}{|c|}{$+\mathrm{EGTA}(2 \mathrm{mM})$} & $2044(94 \pm 2)$ \\
\hline \multicolumn{3}{|c|}{+ WGA $(25 \mu \mathrm{g} / \mathrm{ml})$} & $449(21 \pm 3)$ \\
\hline \multicolumn{3}{|c|}{$-N P-40$} & $875(40 \pm 2)$ \\
\hline \multicolumn{4}{|c|}{$-\mathrm{NP}-40+$ ホスファ* } \\
\hline \multicolumn{3}{|c|}{ ジルセリン $(20 \mu \mathrm{g} / \mathrm{ml})$} & $1599(75 \pm 3)$ \\
\hline
\end{tabular}

果, カラム溶出液中に WGA 感受性のATPase 活性を 見出した：この酵素は膜酵素の性質を有し，また既報の

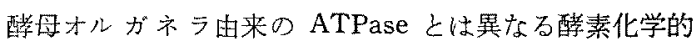
性質を有する新しいるのであることが確認された（表 5). 動物細咆の核孔にもWGA 結合蛋白が存し, in vivo での WGA の添加が核膜に扣ける高分子輸送を阻 䂮することが報告されている(30)が WGA 感受性の核膜 醭素の存在を確認したのは筆者らが初めてである。

以上述べてきたよらに筆者らは䤃母の性フェロモンの 作用について種々の側面から主として生化学的手法を用 いて㛟討を加光てきた，近年の分子遗伝学的手法の進歩 に上り醉母，とくにS. cerevisiae は真核生物 生命現象 の解析以真核生物の大腸菌と称される纪どに広く用いら れるに至っている。しかし遺伝学的に明らかにされた系 のうら生化学的震付けが得られているものは李だ生だ少 ない、籍者らの確立してきた系をさらた発展させ，この 間のギャップを埋好てくことができればと考总てい s.

本研究は広島大学名誉教授福井作藏先生,ならびに広 島大学教授宮川都吉先生の御指頱のもとに行ったもので あります。両先生の長年にわたる御指導, 御鞑撻之暖か い励ましに深く感謝いたします。研究の遂行に㘯たりま しては広島大学工学部生物物理化学教室卒業生の皆様を はじあ多くの方々の御協力を得ました：また広島大学工 学部酶醇工学科の諳先生方には貴重な御助言をいただき ました。記してここに深謝いたします。
(1) E. Tsuchiya and S. Fukui : Agric. Biol. Chem., 42, 1089 (1978).

(2) Y. Sakagami, A. Isogai, A. Suzuki, S. Tamura, E. Tsuchiya and S. Fukui : Agric. Biol. Chem., 42, 1093 (1978).

(3) Y. Kamiya, A. Sakurai, S. Tamura, N. Takahashi, K. Abe, E. Tsuchiya, S. Fukui, C. Kitada and M. Fujino: Biochem. Bio. phys. Res. Commun., 83, 1077 (1979).

(4) R. J. Anderegg, R. Betz, S. A. Carr, J.W. Crabb and W.Duntze: $J$. Biol. Chem., 263, 18236 (1988).

(5) J.F. Hancock, A.I. Magee, J. E. Childs and C. J. Marshall : Cell, 57, 1167 (1989).

(6) E. Tsuchiya, S. Fukui, Y. Kamiya, Y. Sakagami and M. Fujino: Biochem. Biophys. Res. Commun., 85, 459 (1978).

(7) E. Tsuchiya and S. Fukui:Biochem. Biophys. Res. Commun., 85, 473 (1978).

(8) T. Miyakawa, M. Nishihara, E. Tsuchiya and S. Fukui : J. Bacteriol., 151, 1184 (1982).

(9) T. Miyakawa, M.Kaji, T. Yasutake, Y.K. Jeong, E. Tsuchiya and S. Fukui: $J$. Bacteriol., 162, 294 (1985).

(10) T.Miyakawa, M.Kaji, Y.K. Jeong, E. Tsuchiya and S.Fukui : J. Bacteriol., 169, 1626 (1987).

(11) T. Miyakawa, T. Tachikawa, Y.K. Jeong, E. Tsuchiya and S. Fukui : J. Bacteriol.; 162, 1304 (1985).

(12) T. Miyakawa, T. Tachikawa, Y.K. Jeong, E. Tsuchiya and S.Fukui : Biochem. Biophys. Res. Commun., 143, 893 (1987).

(13) F. Cross: Ann. Rev. Cell Biol., 4, 429 (1988).

（14）中山直樹，宮岛有子：「細胞内シグナル伝達機 構」，新井賢一編，秀潤社，1989， p. 42 .

(15) T. Tachikawa, T. Miyakawa, E. Tsuchiya and S. Fukui : Agric. Biol. Chem., 61, 1209 (1987).

(16) J.R. Pringle and L.H. Hartwell: in "The Molecular Biology of the Yeast Saccharo. myces cerevisiae," ed. by J.N. Strathern, E. W. Jones and J.R. Broach, Cold Spring Harbor Lab., 1981, p. 97.

(17) S. I. Reed : Genetics, 95, 561 (1980).

（17）福地 健, 鈴木秀明, 鞍野克司, 土菿英子, 福 井作葴，宮川都吉：農化，64，414（1990).

(19) E. Tsuchiya and S. Fukui : Agric. Biol. Chem., 50, 2963 (1986).

(20) 大知襀一, 安楽泰宏：蛋白質 核酸 酵素， 33 2300 (1988).

(21) B. Lewin : Cell, 61, 743 (1990).

(22) K. Kamimura, E. Tsuchiya, T. Miyakawa 
and S. Fukui: Curr. Microbiol., 6, 175 (1980).

(23) E. Tsuchiya and S. Fukui : Agric, Biol. Chem., 47, 907 (1983).

(24) K. Kamimura, E. Tsuchiya, T. Miyakawa and S. Fukui: Agric. Biol. Chem., 47, 1093 (1983).

(25) E. Tsuchiya, K. Kimura, T. Miyakawa and S. Fukui: Nucleic Acids Res., 12, 3143 (1984).
(26) L. H. Johnston : Curr. Opinion Cell Biol., 2, 274 (1990).

(27) L. Gerace: Ann. Rev. Cell Biol., 4, 335 (1988).

(28) E. Tsuchiya, S. Shakuto, T. Miyakawa and S. Fukui : J. Bacteriol., 170, 547 (1988).

(29) E. Tsuchiya, K. Hiraga, S.Fukui and T. Miyakawa : FEBS Lett., 250, 285 (1989).

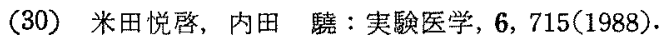

